Annie O'Connor

\title{
SENTENCING THE KILLERS OF GAY MEN SINCE THE ABOLITION OF PROVOCATION IN NEW ZEALAND: HAVE THE COURTS REFLECTED COMMUNITY CONCERNS?
}

Submitted for the LLB (Honours) Degree

Faculty of Law

Victoria University of Wellington

2013 


\section{Contents}

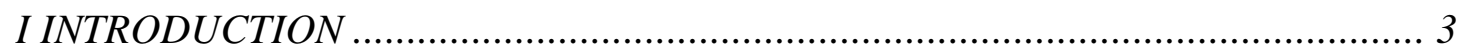

II REASONS FOR THE ABOLITION OF THE PARTIAL DEFENCE OF PROVOCATION

III THE PROBLEMATIC USE OF PROVOCATION IN HOMOSEXUAL ADVANCE

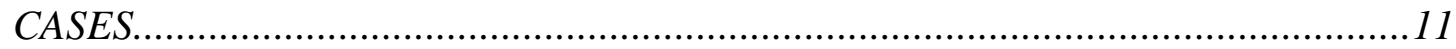

IV PROVOCATION AS AN ISSUE FOR SENTENCING JUDGES...........................13 A AFTER ABOLITION: THE COURT OF APPEAL GUIDELINE JUDGMENT - HAMIDZADEH V

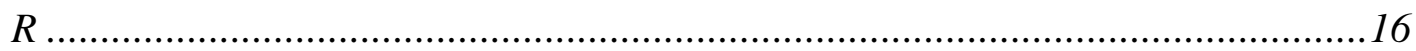

V CASE COMPARISON: HAS ANYTHING CHANGED SINCE PROVOCATION WAS

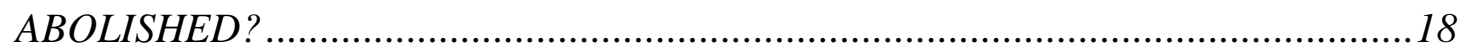

A SENTENCING IN CASES OF A MANSLAUGHTER VERDICT............................................18

VI SECTION 9(1)(H): HOW HATE CRIME LEGISLATION FITS IN WITH HOMOSEXUAL ADVANCE CASES ..............................................................22

A THE TENSION BETWEEN S 9(1)(H) AND THE PARTIAL DEFENCE OF PROVOCATION IN

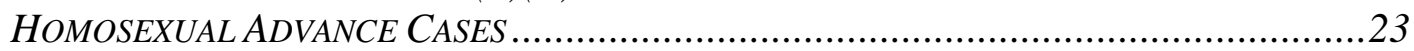

B WHY S 9(I)(H) IS IMPORTANT IN HOMOSEXUAL ADVANCE CASES.............................24

VII CASE COMPARISON: SENTENCING IN CASES OF A MURDER

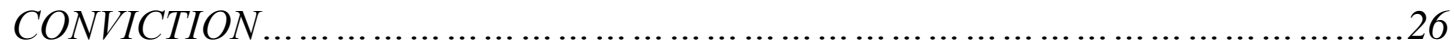

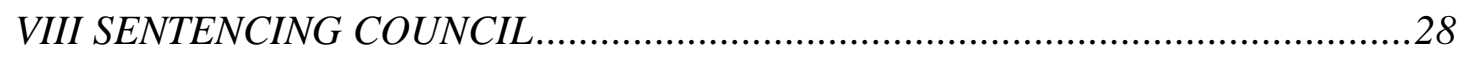

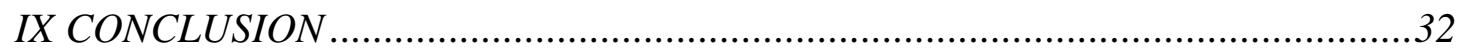

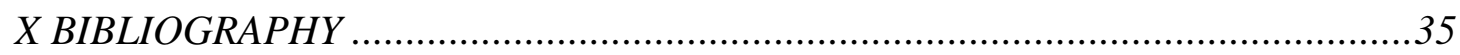




\section{Sentencing the killers of gay men since the abolition of provocation in New Zealand: have the courts reflected community concerns?}

This paper discusses sentencing in New Zealand homicide cases in which the offence was prompted by a homosexual advance in light of the abolition of the partial defence of provocation. The author argues that, despite the concerns around sentencing in homosexual advance cases that partly led to the abolition of the partial defence, there has been no real change in the way these cases are being sentenced. This paper suggests that prejudice against homosexuals may be a significant contributing factor toward the low sentences that have continued to be given to offenders in unwanted homosexual advance cases.

Key words: Sentencing, homosexual advance, provocation, abolition

\section{Introduction}

In 2007 Ronald Brown was viciously beaten in his home and left to die with the broken neck of a banjo pushed into his mouth. ${ }^{1}$ His killer, Hungarian tourist Ferdinand Ambach, argued that Brown provoked his own death with a brief, nonviolent sexual advance towards Ambach. The jury in this case accepted his explanation. Ambach was found not guilty of murder, and was eventually sentenced to 12 years imprisonment for manslaughter. Even though Ambach intended to kill Brown, he was not sentenced to life imprisonment due to Brown's alleged conduct, which many would not consider to be a sufficient explanation for homicidal loss of self-control.

${ }^{1} R v$ Ambach HC Auckland CRI-2007-004-27374, 18 September 2009. 
Partly in response to public disquiet about the use of the defence, ${ }^{2}$ New Zealand Parliament abolished the partial defence of provocation in 2009. This defence operated to reduce a charge of murder to manslaughter in cases where the offender was provoked in a manner sufficient to deprive an ordinary person of self-control, and it was this provocation that induced the offender to commit the act of homicide. While the Law Commission had previously recommended abolition of the defence in New Zealand on more than one occasion, ${ }^{3}$ it was the 2008 case of $R v$ Weatherston that brought the issues surrounding provocation into the public eye. ${ }^{4}$ The potential use of the defence by Weatherston sparked public outrage, as it was seen as inappropriate victim blaming. 5

The defence also gained public notoriety due to its successful use in homicide cases that involved an unwanted, non-violent, homosexual advance by the victim. It was argued, often successfully, that this type of advance constituted severe provocation justifying a homicidal loss of self-control in the ordinary person. Many argued that the use of provocation in these cases was discriminatory against the homosexual community. ${ }^{6}$

This paper will first discuss the partial defence of provocation and some of the arguments that were used to support the case for abolition. It will outline why the

\footnotetext{
${ }^{2}$ Elisabeth McDonald "Provoking Law Reform: Feminism, Queer Theory and the Legislative Agenda" in Claire Chambers and Dean Knight (eds) We the People(s) (Victoria University Press, Wellington, 2011) 237 at 243.

${ }^{3}$ New Zealand Law Commission The Partial Defence of Provocation, ('The Partial Defence of Provocation') (NZLC R98, Wellington, 2007), New Zealand Law Commission Some Criminal Defences with Particular Reference to Battered Defendants (NZLC R 73, Wellington, 2001).

${ }^{4} R v$ Weatherston [2011] NZCA 276.

${ }^{5}$ Edward Gay "Partial defence of provocation set to be dumped" The New Zealand Herald <nzherald.co.nz>.

${ }^{6}$ Alison Laurie "'Homosexual Panic' defence must go" The New Zealand Herald <www.nzherald.co.nz>.
} 
partial defence was eventually abolished, including the role of the Law Commission's 2007 Report The Partial Defence of Provocation ("the Report") in that process. The focus will be on the use of provocation in unwanted homosexual advance cases, with discussion centering on why there was such opposition to the use of the partial defence in these cases. It will consider how the use of the defence of provocation worked in favour of heterosexual men, and how it operated to legitimise violence against homosexual men.

In considering the event that provocation was to be abolished, the Law Commission acknowledged that steps would need to be taken to ensure that relevant provocation by victims would be taken into account in appropriate cases. Following abolition, the Law Commission suggested that judges should consider the effect of alleged provocation at sentencing stage. ${ }^{7}$ The effect of the abolition of the partial defence of provocation was therefore to shift the focus away from the jury and onto the role of the sentencing judges. This means that the burden now lies solely on judges to acknowledge the relevant issues at sentencing stage.

The Report found that a significant proportion of all successful provocation cases involved an unwanted homosexual advance. ${ }^{8}$ This paper will look at some of these cases in detail, and will compare the sentences given with those in similar, postabolition cases. It will show that, despite the change in law, sentencing in these cases remains largely unchanged. This paper suggests that this may be because, while provocation must be of a high level to reduce a murder sentence from life imprisonment, provocative actions of the victim may still substantially reduce a

7 The Partial Defence of Provocation, above n 3, at [183].

${ }^{8}$ At [102]. 
sentence where the charge is found to be manslaughter; suggesting that sympathy for an offender who has experienced an unwanted homosexual advance is still able to significantly affect the way a judge or jury decides in homosexual advance cases.

This paper will argue that one of the issues that should be being addressed in the aforementioned cases is whether a crime has been committed because of a homophobic motivation. This is an aggravating factor under $\mathrm{s} 9(1)(\mathrm{h})$ of the Sentencing Act 2002. This paper discusses the previous tension between provocation and s 9(1)(h), and how abolition of the partial defence has removed any cause for a sentencing judge to be reluctant to recognise a homosexual advance homicide as a hate crime. It will consider the lack of recognition of this section in such cases since abolition, and what could be done to ensure that this aggravating factor is given appropriate consideration.

This paper will then discuss one of the Law Commission's recommendations, which was to establish a Sentencing Council to provide guidance to sentencing judges. ${ }^{9}$ A Sentencing Council may have been effective in ensuring that s 9(1)(h) was considered in relevant homosexual advance cases. The introduction of a Sentencing Council would also have addressed the concerns of some groups who did not initially support abolition of the defence of provocation, such as Women's Refuge, on the basis that this would be a method of ensuring community input into the identification of relevant aggravating and mitigating factors. However, a Sentencing Council was not established. This paper argues that the failure to create any sort of guidance for sentencing judges has left a void in terms of cases involving alleged provocation by

\footnotetext{
${ }^{9}$ The Partial Defence of Provocation, above n 3, at [205].
} 
the victim. It concludes by arguing that the failure to establish a Sentencing Council, as recommended, has meant that community concerns about the kinds of excuses offered for killing gay men, which were validated through the successful use of the defence of provocation, remain.

\section{Reasons for the Abolition of the Partial Defence of Provocation}

The partial defence of provocation was contained in s 169 of the Crimes Act 1961. In homicide cases where there had been provocation by the victim, the defence could be used to reduce a charge of murder to manslaughter. Section 169 required that the offender had been provoked to such an extent that it was sufficient to deprive a person having the self-control of an ordinary person, but otherwise the characteristics of the offender, of the power of self-control. It then had to be shown that it was this loss of self-control that caused the offender to kill their victim. The judge would decide whether or not the defence should be put to the jury as a matter of law, and it was then left to the jury to determine that the prosecution had not disproved the availability of the partial defence beyond reasonable doubt, in order for manslaughter to be the verdict.

Historically, provocation was used to reduce charges for offences which society felt carried lowered culpability. This was because, as the victim either instigated the conflict or did something to wrong the offender, there was therefore a moral wrong by both parties. ${ }^{10}$ The partial defence implied that while it may not be morally right to kill somebody for their provoking action, a person is in some way excused for taking

\footnotetext{
${ }^{10}$ A J Ashworth "The Doctrine of Provocation" (1976) 35 Cambridge LJ 292 at 307.
} 
punitive action against someone who has intentionally caused great moral offence. ${ }^{11}$ When a legal system requires that a mandatory sentence of life imprisonment be given for murder, overly harsh sentencing may occur in some cases. Where the offender truly lost the power of self-control due to the provocative action of the victim, the existence of the partial defence may be justified to ensure that a sentence lower than life imprisonment, which is more reflective of the offender's culpability, may be imposed.

Until the passing of the Sentencing Act 2002, there was a mandatory life imprisonment for murder. Now s 102 of the Act provides for a presumption of life imprisonment for murder, which can be rebutted where such a sentence would be "manifestly unjust". ${ }^{12}$ This means that the circumstances of the offence, including the actions of the victim, may be taken into account at sentencing stage, and may rebut the presumption of life imprisonment if appropriate. As this allows for some discretion in the sentencing of murders, the partial defence of provocation was no longer a crucial part of New Zealand's law, with regard to the recognition of decreased culpability.

The Crimes (Provocation Repeal) Act was passed in December 2009. The defence of provocation could no longer be relied on for homicides committed after the Act came into force. There had been much discussion about the flaws of the defence and inconsistencies in the way it had been applied leading up to the abolition, as well as concerns expressed regarding how the courts would adjust sentencing without the defence.

\footnotetext{
${ }^{11}$ At 307.

${ }^{12}$ The Sentencing Act 2002, s102.
} 
The Law Commission's 2007 Report detailed the reasons in support of their recommendation to abolish the defence of provocation. One reason was the conceptual flaw in the partial defence identified by the Law Commission; uncertainty of whether or not there is actually such a thing as loss of self-control. It is not clear that this phenomenon genuinely exists. ${ }^{13}$ It has been suggested that self-control is actually moderated by reason. ${ }^{14}$ The law has no way of determining scientifically whether the behavior of a defendant was simply due to extreme anger giving way to uncontrolled behavior, or a genuine pathological impulse which the defendant truly could not control. ${ }^{15}$

Even if loss of self-control does exist, it is argued that the ordinary (reasonable) person would not be susceptible to it, and certainly not to loss of self-control so extreme as to result in homicide. The Law Commission reasoned that this is not an experience that an ordinary person would have, that only the most extraordinary person would react in this way. ${ }^{16}$ The Report states that this is the defence's "most telling flaw". ${ }^{17}$

If loss of self-control does not truly exist, then the partial defence was essentially being used to inappropriately excuse those offenders who lashed out in a homicidal rage. There were concerns that the defence was based on "archaic notions about

\footnotetext{
${ }^{13}$ At [88].

${ }^{14}$ At [88].

${ }^{15}$ Warren J Brookbanks “'I lost it' - rage and other excuses: rethinking loss of self-control in provocation" (2006) 31 Alt LJ 186 at 187.

${ }^{16}$ At [89].

17 At [89].
} 
violence", and that society no longer accepted an affront to dignity as a reasonable excuse for homicidal anger. ${ }^{18}$

The flawed concept behind provocation was not the only problem with the partial defence. Practically, it was also extremely complicated for juries to consider, despite the extensive directions they were given. These directions were that the defendant's characteristics could be considered in light of the gravity of provocation, but they could not be considered in regard to the defendant's ability to exercise self-control. ${ }^{19}$ The correctness of this approach caused much debate, as it seems that any characteristics that would affect how strongly a defendant felt the provocation would also be significant when considering the ability of a defendant to exercise selfcontrol. $^{20}$

Another way the partial defence appeared to be flawed in practice was that the defence was biased in favour of the interests of heterosexual men. The defence of provocation works to benefit heterosexual men by recognising what is dominantly a male reaction as mitigating their crime, but it works to the detriment of women, who rarely kill at all, comparatively speaking ${ }^{21}$ but who are often the victims of such a provoked response. ${ }^{22}$ It also works against homosexual men in that it has been repeatedly used in situations where heterosexual men have believed their masculinity to be "fundamentally threatened". ${ }^{23}$ This often refers to an unwanted homosexual

\footnotetext{
${ }^{18}$ Gay, above $\mathrm{n} 5$.

${ }^{19}$ The Partial Defence of Provocation, above n 3, at [83].

${ }^{20}$ At [83].

${ }^{21}$ In 2012, of the 25 people convicted of murder, 2 were women <http://nzdotstat.stats.govt.nz> Statistic NZ Website.

22 Joshua Dressler "When 'Heterosexual' Men Kill 'Homosexual' Men: Reflections on Provocation Law, Sexual Advances, and the 'Reasonable Man' Standard" (1995) 85 J Crim L \& Crim 726 at 754.

${ }^{23}$ The Partial Defence of Provocation, above n 3, at [96].
} 
advance, which successful use of the partial defence affirmed is a situation in which the ordinary person would respond with rage and violence.

The use of provocation in the context of an unwanted homosexual advance was very contentious because of the discriminatory way that it operated against homosexual men. ${ }^{24}$ The next section of this paper will discuss in more detail some of the issues surrounding the use of provocation in these types of cases.

\section{The Problematic Use of Provocation in Homosexual Advance Cases}

The use of the partial defence of provocation in circumstances of an alleged nonviolent unwanted homosexual advance was problematic for a number of reasons.

The defence was often raised in cases where a man alleged to have felt so strongly about a sexual advance from another man that he lost the power of self-control, which caused him to kill his victim. Cases of this nature where provocation was successful did not necessarily involve violent or even aggressive sexual advances. Often a brief touch in an overly familiar way was all that had occurred to cause the offenders to allegedly lose power of self-control, which then caused them to kill their victims.

The fact that a loss of self-control leading to homicidal violence was deemed to be a reaction of the "ordinary person" under the requirements of the defence implied that homophobia is an acceptable trait, and one that others can and should feel sympathy

\footnotetext{
${ }^{24}$ The Partial Defence of Provocation, above $\mathrm{n} 3$, at [96].
} 
for. ${ }^{25}$ The use of provocation in homosexual advance situations protected a heterocentric view of masculinity that promotes the notion that violence against homosexual men is acceptable in order to affirm the masculinity of the offender. ${ }^{26}$

By upholding this view of masculinity, successful use of provocation in unwanted homosexual advance cases affirmed the idea that violent reactions to gay men were justifiable and understandable. As Gary Comstock points out, females are often subjected to the sorts of advances that are argued to have caused murderous outrage in some homosexual advance cases. ${ }^{27}$ It seems very unlikely that a jury would find, for example, that a man placing his hand upon the leg of a woman would be an acceptable excuse for the woman to lash out in homicidal rage and kill him. The fact of the victims' homosexuality was the additional element that distinguished homosexual advance cases from other types of sexual advances that would almost certainly not have fulfilled the requirements of s 169. By allowing these non-violent unwanted homosexual advances to be considered by the jury as a feasible class of provocation, judges were allowing and even encouraging homophobia and excusing disproportionate violence against gay men. ${ }^{28}$

Robert B Mison discusses society's deeply engrained homophobia, and says that this heterosexism and disapproval of homosexuality are beliefs so much a part of culture they are not experienced explicitly. Instead they seem part of the

\footnotetext{
${ }^{25}$ New Zealand Law Commission The Partial Defence of Provocation, above $\mathrm{n}$ 3, at [96].

${ }^{26}$ Antony Whitehead "Man to Man Violence: How Masculinity May Work as a Dynamic Risk Factor" (2005) 44 How J Crim Just 411 at 417.

${ }^{27}$ Gary Comstock "Dismantling the Homosexual Panic Defense" (1992) Law and Sexuality 81 at 100.

${ }^{28}$ Adrian Howe "More Folk Provoke Their Own Demise (Homophobic Violence and Sexed Excuses Rejoining the Provocation Law Debate, Courtesy of the Homosexual Advance Defence)" (1997) 19 Sydney LR 336 at 340.
} 
individual's rational ordering of their perceptions of their world. ${ }^{29} \mathrm{He}$ argues that the use of provocation in unwanted homosexual advance cases is a judicial affirmation and legitimisation of society's homophobia. ${ }^{30}$ The defence allowed juries to express their homophobia through a legitimate channel. Juries may unconsciously pass negative social judgment on the victim's homosexuality, and therefore the defence of provocation may seem a natural way to express their disapproval. $^{31}$

The abolition of the partial defence of provocation was a necessary step away from this legal affirmation that homophobia was normal and acceptable. However, relevant provocation issues still need to be considered in appropriate cases. The next section of this paper will consider what was recommended in terms of dealing with provocation post abolition.

\section{Provocation as an Issue for Sentencing Judges}

As mentioned previously, the abolition of the partial defence of provocation meant that factors that could previously have reduced a conviction of murder to manslaughter would now be taken into account at sentencing stage. ${ }^{32}$

The Law Commission's 2007 Report addressed some of the concerns that had arisen regarding sentencing upon abolition of the defence.

\footnotetext{
${ }^{29}$ Robert Mison "Homophobia in Manslaughter: The Homosexual Advance as Insufficient Provocation" (1992) 80 Cal LR 133 at 177.

${ }^{30}$ At 177.

${ }^{31}$ Christina Pei-Lin Chen "Provocation's Privileged Desire: The Provocation Doctrine, 'Homosexual Panic', and the Non-Violent Unwanted Sexual Advance" (2000) 10 Cornell JL \& Pub Pol 195 at 212.

${ }^{32}$ At [184].
} 
One of the concerns discussed in the Report was the fact that there may be less transparency if the relevant arguments were dealt with at sentencing stage. However, the Law Commission argued that consideration of provocation at sentencing would actually lead to greater transparency. This is because judges are required to state their reasoning for the aggravating and mitigating factors considered in open court, which is in contrast with cases where provocation did not succeed with a jury, whose deliberations are private, so very little would be articulated about the issues involved and how they were dealt with. ${ }^{33}$

In cases prior to abolition, when provocation was put to the jury alongside other partial defences such as lack of intent, it was impossible to know which defence was the basis for a conviction of manslaughter. In terms of homosexual advance cases, the requirement that judges deal with provocation issues at sentencing had the potential to be a positive shift in regard to transparency. If a judge considers a homosexual advance to be a significant mitigating factor, this must be stated. The factors that aggravate or mitigate a sentence are open to public critique and judicial review if taken on appeal. This removes the secrecy around sentencing in homosexual advance cases, and therefore may discourage judges from sentencing these offenders based on prejudice against homosexuals.

Another matter discussed in the Report was that defendants who would previously have succeeded with the defence of provocation would be at risk of harsher sentences upon repeal of s 169 .

\footnotetext{
${ }^{33}$ At [187].
} 
The Report considered the idea that, in order to amend the issue of harsher sentencing, measures may have been required to ensure that adequate consideration of mitigating factors was given at sentencing. ${ }^{34}$ The possible modification of s 102 of the Sentencing Act 2002 to ensure that this consideration occurred was discussed in the Report. This section permits a defendant to be given a lower sentence if to impose life imprisonment in the particular circumstances of the case would be manifestly unjust. The case of $R v$ Rapira stated that this is a high threshold test, and would be met in exceptional cases only. ${ }^{35}$ One of the suggestions given was to lower the threshold from manifestly unjust to some lesser threshold to weaken the presumption of life imprisonment. However, this had the potential to be problematic in that it could undermine the important message that life imprisonment is the norm for intentional killing. ${ }^{36}$ The Report found that the current test for manifest injustice is arguably flexible enough to allow existing substantial mitigating factors to rebut the presumption in deserving cases. ${ }^{37}$ The Court of Appeal case of $R v$ Hamidazeh has since confirmed that high-level provocation may be a relevant factor under s $102 .{ }^{38}$

Another suggestion was to include in s 102 examples of the principal types of mitigation that are likely to rebut the presumption. ${ }^{39}$ However, as the complexities of proving provocation at trial caused substantial difficulty, it was thought that to add this type of specific guideline would be extremely difficult to accomplish without introducing the same problems that arose with the specifics of the partial defence. ${ }^{40}$

\footnotetext{
34 At [195].

${ }^{35} R$ v Rapira [2003] 3 NZLR 794 at [121].

36 At [200].

${ }^{37}$ At [200].

${ }^{38}$ Hamidzadeh v $R$ [2012] NZCA 550.

${ }^{39}$ At [201].

${ }^{40}$ At [202].
} 
The Law Commission ultimately looked to the policy reason for abolition, which was that the defendants who successfully relied on provocation were not necessarily more deserving of favourable treatment than others who were convicted of murder. They found that it would therefore not make sense to continue to ensure that lower sentences are given to those defendants following the abolition of the defence, unless they meet the already established manifestly unjust test. ${ }^{41}$ The Law Commission recommended therefore that no changes be made to the Sentencing Act 2002, and upon abolition no amendments were made to accommodate defendants who may previously have succeeded under s 169.

\section{A After Abolition: The Court of Appeal Guideline Judgment - Hamidzadeh v R}

In Hamidzadeh $v R$, the Court of Appeal comprehensively considered when provocative conduct should be taken into account to meet the manifest injustice threshold in murder cases. The Court recognised that principles of sentencing were less relevant in murder cases where there is a specific sentencing regime in place. However, they found that one sentencing principle of particular relevance in murder cases was the degree of culpability of the offender, which is set out in s $8(a)$ of the Sentencing Act 2002. ${ }^{42}$

The Court found that loss of control might be a factor which is relevant to culpability, and that a killing which occurs due to a sudden and justified loss of self-control may be less culpable than one involving a calculated and controlled response. ${ }^{43}$ The Court stated that the approach to provocation sentencing should be fact-dependent, and they

\footnotetext{
${ }^{41}$ At [196].

${ }^{42}$ At [53] per Randerson J.

${ }^{43}$ At [60] per Randerson J.
} 
stressed that a flexible approach is required. ${ }^{44}$ While the Judges felt that attempting to set out an exhaustive list of relevant considerations should be avoided, they did include some factors that may be relevant in provocation cases. ${ }^{45}$ These included the nature, duration and gravity of the alleged provocative conduct; the timing of any response by the offender; whether the response was proportionate to the nature, duration and gravity of the provocation; whether the provocation was (or remained) an operative cause of the offender's response; and whether the provocative conduct was such as to reduce the offender's culpability in all the circumstances. ${ }^{46}$

The Court of Appeal stated that as well as applying the principles in s 8 of the Sentencing Act, a court should also apply the aggravating and mitigating factors in ss 9 and $10 .{ }^{47}$ Provocation may be a relevant consideration under s $9(2)(\mathrm{c})$, which states that the conduct of the victim may be a mitigating factor. Despite the consideration of these sections, the Court was careful to note that provocation will not warrant a sentence of less than life imprisonment other than in exceptional circumstances. ${ }^{48}$ The Court stated that the requirement in murder cases to demonstrate manifest injustice must be kept firmly in mind, and that a high level of provocation will ordinarily be required to warrant the imposition of something less than life imprisonment under $\mathrm{s}$ $102 .^{49}$ This high level test means that the type of non-violent provocation previously argued successfully in homosexual advance cases would hopefully not be enough to rebut the presumption of life imprisonment.

\footnotetext{
${ }^{44}$ At [62] per Randerson J.

${ }^{45}$ At [62] per Randerson J.

${ }^{46}$ At [62] per Randerson J.

${ }^{47}$ At [72] per Randerson J.

${ }^{48}$ At [72] per Randerson J.

${ }^{49}$ At [62] per Randerson J.
} 
This judgment is helpful as a general guide for sentencing judges in provocation cases post abolition. However, in terms of homosexual advance cases, more specific guidance is still needed in order for sentencing to reflect community concerns around the sentencing of offenders in these cases. This is because, although in murder cases the threshold to rebut the presumption of life imprisonment is set at a high level, where the verdict of the court is manslaughter, there is no such guidance for how provocation may affect the sentence. Manslaughter sentences vary enormously, and there is a wide scope for provocation to be given very significant weight in the sentencing of manslaughter cases.

The following comparison of cases from before and after the abolition of the defence of provocation shows that, despite the repeal of s 169 , there has so far been no real change in the end result of sentences imposed in homosexual advance cases. Although provocation may only rebut the presumption of life imprisonment for murder where the provocation is of a high level, other issues now arise in terms of how alleged provocation may implicitly affect sentencing.

V Case Comparison: Has Anything Changed Since Provocation was Abolished?

\section{A Sentencing in Cases of a Manslaughter Verdict}

This section will compare sentencing in two unwanted homosexual advance cases, one that occurred before and one after the abolition of the partial defence of provocation. Both of these cases resulted in a manslaughter verdict. The purpose of 
this comparison of cases is to determine whether community concerns regarding the excusing of violence in homosexual advance cases have been adequately addressed by the abolition of the defence of provocation.

In 2003, 16 year old Amsheen Ali killed his uncle by marriage, Colin Hart by stabbing him in the chest, neck and back. Ali alleged that Hart had made a sexual advance toward him by rubbing his thighs and attempting to kiss his neck. ${ }^{50}$ Ali had previously put a knife in the couch, which after the advance he took out and stabbed Hart with five times. He then left the house, taking with him Hart's wallet, credit cards and car keys, before returning to retrieve the knife he had used. He then drove around for the next few hours in Hart's car with his friends. He told these friends about the killing, but made no mention of a homosexual advance of any kind. ${ }^{51}$ In court it was submitted that Ali's casual reaction following the attack was not callous indifference as it may have appeared, but rather shock-induced denial. ${ }^{52}$

Williams $\mathbf{J}$ directed the jury that the partial defence of provocation was available as a matter of law, as a homosexual assault might be met with feelings of revulsion that could lead the ordinary person to a loss of self-control. ${ }^{53}$ It was found that Hart's advance provoked Ali to such an extent that would cause the ordinary person to lose the power of self-control, and Ali was therefore convicted of manslaughter but not murder. Williams $\mathbf{J}$ concluded his sentencing comments by expressing his sympathy for Ali's family, and his hope for their continued support of Amsheen. ${ }^{54}$ Williams J's sentencing judgment is telling in that it shows that the Judge considered Ali to be not

\footnotetext{
${ }^{50} R$ v Ali CRI2003-292-1224, 19 August 2004, at [4] per Williams J.

${ }^{51}$ At [8] per Williams J.

${ }^{52}$ At [13] per Williams J.

${ }^{53} R$ v Ali \& Nadan CRI-2003-292-1224, 22 July 2004 at [38] per Williams J.

${ }^{54} R v A l i$, above $\mathrm{n} 52$ at [21] per Williams $\mathrm{J}$.
} 
only an offender in this case, but also a victim. He was openly sympathetic about the non-violent, but "repulsive" homosexual advance that Ali experienced. Ali was sentenced to only three years imprisonment for his crime. ${ }^{55}$

The 2011 case of $R v$ Ahsee is a case that has occurred since the abolition of the defence of provocation. It involved the killing of 59 year old Denis Phillips by Willie Ahsee, a 16 year old who Phillips had known for a few weeks, and who had previously visited his home to do boxing and weight training. ${ }^{56}$ Ahsee went to Phillips' house on the night of the incident, and again did some training with Phillips. The two men then began to drink wine and spirits together, and they both became very intoxicated. During the night, Phillips allegedly touched Ahsee on the upper thigh, and then a while later again touched him on his ear. Ahsee reacted by grabbing a serrated knife, and stabbing Phillips several times in the chest and neck. He later said that he did not mean to hit Phillips; he simply wanted to get him "out of the way". ${ }^{57} \mathrm{He}$ then left the house, taking with him Phillips' laptop, cellphone and several items of his clothing. Ahsee was described as being highly distressed after the incident, and he confessed what he had done to police the next day.

Ahsee defended his acts on the basis of the defence of accident, self-defence and the partial defence of lack of murderous intent. The jury found him to be guilty of manslaughter, which means that while they did not accept the defences of accident or self-defence as being met, they must have still found that he lacked murderous intent when he repeatedly stabbed Phillips. ${ }^{58}$

\footnotetext{
${ }^{55} R v A l i$, above $\mathrm{n} 50$ at [20] per Williams J.

${ }^{56} R v$ Ahsee, CRI-2010-055-2018, 15 December 2011 at [4] per Asher J.

${ }^{57}$ At [16] per Asher J.

${ }^{58}$ At [15] per Asher J.
} 
At sentencing, Asher $\mathbf{J}$ stated that, as Ahsee was not a homosexual he therefore would have found the advance "very difficult to deal with". ${ }^{59} \mathrm{He}$ found that the sexual advance was to be considered as a significant mitigating factor, along with his youth and remorse. The aggravating factors included the use of a weapon, the extreme violence, and the harm that was done. Ahsee was sentenced to only five years imprisonment.

These cases have elements that are remarkably similar, and so comparison is easily done. The judge in both cases expressed sympathy for the young offender who had experienced an unwanted homosexual advance. Both juries found that the offenders' culpability was lower than for murder, despite the offenders having stabbed their victims multiple times in a way that is difficult to see as other than intentional. The low sentences given of three and five years show that, despite the abolition of provocation, the concerns around sentencing in homosexual advance cases remain.

These cases illustrate that there has not been the change in sentencing in homosexual advance cases that advocates for the abolition of the partial defence of provocation hoped for. While provocation can no longer mitigate a sentence from murder to manslaughter, abolition seems to have raised other issues in regard to sentencing. Where an offender is found guilty of murder, Hamizadeh tells us that provocation can rebut the presumption of life imprisonment only where it is of a very high level. As the cases above show, these homosexual advance cases usually involve a brief unwanted touch, which is unlikely to be of the required gravity to rebut the

\footnotetext{
${ }^{59}$ At [27] per Asher J.
} 
presumption. It therefore seemed hopeful that after the abolition of provocation, this type of very low sentencing for homosexual advance cases would not be possible.

However, while provocation may not ordinarily be enough to rebut the presumption of life imprisonment for murder, as the case of Ahsee shows, there is still the possibility that a homosexual advance by a victim may be considered to lower an offender's culpability considerably, despite the offender no longer being able to rely on the partial defence of provocation. This is shown through the sentencing comments by the judge in Ahsee, but also possibly through the decision of the jury who found Ahsee to be guilty of manslaughter. Lack of intent is a confusing conclusion for the jury to have reached, considering Ahsee's act of repeatedly stabbing Phillips with a knife. It is my submission that it may have been that, despite no longer having the partial defence of provocation available to them, the jury was nonetheless looking for a reason to acknowledge the homosexual advance as lowering Ahsee's culpability, and that this was the true reason for the manslaughter conviction that was given.

\section{Section 9(1)(h): How Hate Crime Legislation Fits in with}

\section{Homosexual Advance Cases}

The above case comparison focused on the fact that homosexual advances have been wrongly used to mitigate an offender's sentence by judges and juries. However, this paper will also argue that if the motivation for a homicide is a non-violent homosexual advance, it should be recognised as a hate crime, and taken into account as an aggravating factor under New Zealand's hate crime legislation, s 9(1)(h) of the Sentencing Act 2002. 
Section 9(1)(h) states that if an offender committed an offence partly or wholly because of hostility towards a group of persons who have an enduring common characteristic such as race, colour, nationality, religion, gender identity, sexual orientation, age, or disability, a sentencing judge must take this into account. ${ }^{60}$ This section is aimed towards recognition of hate crimes, and acknowleges that if the motivation of a crime is based on discrimination, it should aggravate the sentence given to the offender. ${ }^{61}$ The case of Taueki confirmed that this section includes where an offence has been committed partly or wholly because of homophobia. ${ }^{62}$

A The Tension Between $s 9(1)(h)$ and the Partial Defence of Provocation in Homosexual Advance Cases

Before the abolition of provocation, the use of $\mathrm{s} 9(1)(\mathrm{h})$ in unwanted homosexual advance cases was arguably at odds with the operation of the partial defence. ${ }^{63}$ This was because on one hand, the fact that the homicidal reaction was due to a homosexual advance could be used as a mitigatory factor, yet on the other, discriminatory behaviour based on prejudice toward homosexuals was to be considered as an aggravating factor of an offence.

This meant that in homosexual advance cases where the defence of provocation was put to the jury, it may have seemed contradictory for a judge to then also

\footnotetext{
${ }^{60}$ Sentencing Act 2002, s 9(1)(h).

${ }^{61}$ John Ip "Debating New Zealand's Hate Crime Legislation: Theory and Practice" (2005) 21 NZULR 575 at 575.

${ }^{62} R$ v Taueki [2005] 3 NZLR 372 at [31].

${ }^{63}$ Elisabeth McDonald "No Straight Answer: Homophobia as Both an Aggravating and Mitigating Factor in New Zealand Homicide Cases" (2006) 37 VUWLR 223 at 247.
} 
consider the homophobic motivation of the killing as an aggravating factor. By allowing both provocation and s $9(1)(\mathrm{h})$ to exist alongside each other in the same legal system, the New Zealand legislature was sending a confusing message about the tolerance of homophobically motivated hate-crimes. ${ }^{64}$ The intended deterrence effect of s 9(1)(h) was being undermined by the legal legitimisation of homophobic violence through the allowance of the homosexual advance defence.

It is submitted that since the abolition of the partial defence of provocation, there is no longer any reason why s $9(1)(\mathrm{h})$ should not be considered at sentencing in all relevant cases where a crime is motivated by homophobia.

B Why s 9(1)(h) is Important in Homosexual Advance Cases

As the case comparison above shows, no longer allowing provocation to be used in unwanted homosexual advance cases may not on its own be effective in changing the way these cases are sentenced. The homophobic nature of these crimes must also be addressed and denounced by judges when they arise.

In homicide cases where there has been an alleged homosexual advance, it is extremely important that this section is taken into account at sentencing. A man killing another man due to a non-violent sexual advance is a crime that is committed because of hostility towards homosexuals. Rather than being viewed as an advance which could be refused in a non-violent manner, the homosexual nature

\footnotetext{
${ }^{64}$ Scott D McCoy "Homosexual-Advance Defence and Hate Crime Statutes: Their Interaction and Conflict" (2001) 22 Cardozo LR 629 at 633.
} 
of the advance means that it is automatically viewed by the heterosexual man as an assault. ${ }^{65}$

This previously accepted attitude that a homosexual advance is so horrifying an experience for a straight man that he is justified in killing because of it must be altered. Recognition of this type of crime as a hate crime through the use of $s$ $9(1)(\mathrm{h})$ is an important step in this adjustment away from the acceptance of violence against homosexuals.

However, the Judge in Ahsee did not consider s 9(1)(h) when sentencing the offender, showing that the judge did not consider the attack to be a crime committed by the Ahsee because of the victim's homosexuality. It is difficult to see how this conclusion could have been reached based on the disparity between the non-violent provocative conduct, which seemingly required no more than an assertion that it was not wanted, and the violent death of the victim. Mr Phillips' death should have been expressly recognised as a hate crime if the aggravating considerations set out in the Sentencing Act had been correctly applied. Despite the repeal of s 169 and therefore the elimination of the contradiction between the partial defence and s 9(1)(h), sentencing judges in unwanted homosexual advance cases are continuing to ignore this compulsory consideration. This is further illustrated through another comparison of a pre- and post-abolition case, in which the verdict in the post-abolition case was murder.

\footnotetext{
${ }^{65}$ Ben Golder 'The Homosexual Advance Defence and the Law/Body Nexus: Towards a Poetics of Law Reform’ (2004) 11 E Law: Murdoch University Electronic Journal of Law at [35].
} 


\section{Case Comparison: Sentencing in Cases of a Murder Conviction}

A homosexual advance case that occurred after the abolition of the defence of provocation is $R v$ Knight, which can be compared with the previously mentioned preabolition case of $R v$ Ambach. ${ }^{66}$ Ferdinand Ambach, a Hungarian man, was temporarily in New Zealand for a working holiday. In December 2007 he met his victim, Ronald Brown, in a bar in Onehunga, and was invited back to his house for drinks. Ambach claimed that while they were drinking, Brown made an advance by touching his thigh, which Ambach rejected. A short while later Brown made another advance; this time briefly touching Ambach's groin through his clothing. Ambach was apparently so troubled by this advance that he viciously attacked Brown. He hit him over the head multiple times with a banjo, a dumbbell weight, and other weapons. Ambach left Brown struggling to breathe, with the neck of the banjo pushed into his mouth. He continued to ransack the house, throwing things out of the window and at the injured Brown, breaking many of his precious belongings. Brown died two days later from his injuries.

At trial, the partial defences of provocation and lack of murderous intent were put to the jury on the basis of Brown's non-violent sexual advances. The jury found that Ambach was deserving of a conviction of manslaughter rather than murder. ${ }^{67}$ The sentencing judge concluded that due to the prolonged and severe attack, the most likely basis for the jury's finding of manslaughter was provocation. Ambach was sentenced to 12 years imprisonment, with a non-parole period of 8 years.

\footnotetext{
${ }^{66} R v$ Ambach CRI-2007-004-27374, 18 September 2009.

${ }^{67}$ At [12] per Winkelmann J.
} 
In the 2012 case of $R v$ Knight, 21 year old Morgan Knight was hitchhiking near Taupo when Mr Tunnicliffe, a 64 year old ACC beneficiary, stopped to give him a ride. He invited Knight back to his house for lunch and to earn some money trimming trees. Once there, the two men sat and talked in the living room until approximately 1am, at which time Knight says that Tunnicliffe touched his penis through his trousers. Knight reacted by punching him in the head repeatedly, kicking him in the stomach and then, once Tunnicliffe was unconscious, stomping on his head.

Toogood $\mathrm{J}$ recognised that this was an overreaction to a sexual overture, and that the brutality of the attack took him close to the 17 year minimum parole period set out in s 104 of the Sentencing Act. However, he found that mitigating factors such as Knight's youth and remorse brought the appropriate minimum parole period down to ten years. The judge in this case did not expressly consider Tunnicliffe's advance to be a mitigating factor in his sentencing comments, but he also did not consider $\mathrm{s}$ $9(1)(h)$ to be a factor that should aggravate Knight's sentence. ${ }^{68}$

Knight's homicidal reaction to a brief, non-violent homosexual advance strongly suggests that Tunnicliffe's homosexuality was the reason for Knight's hostility. This means that s 9(1)(h) should have been considered, and Mr Tunnicliffe's death should have been given proper recognition as a hate crime. Ten years is the lowest possible minimum parole period that may be given for murder under s 103 of the Sentencing Act. The brutality of the violence inflicted by Knight in this case seems to point to a sentence closer to the 17 year minimum under s 104 as Toogood J originally stated, even after consideration of the mitigating factors discussed. Despite finding that

${ }^{68} R v$ Knight [2012] NZHC 2866 at [7] per Toogood J. 
Knight was guilty of murder, the sentence given to him was only two years longer than the eight years imposed in the very similar pre-abolition case of Ambach. Again, I submit that it is plausible that the sexual advance by Tunnicliffe was the true reason for the imposition of a surprisingly low sentence, despite the inability of the defendant to argue provocation as a partial defence.

If it is true that homosexual advances are still able to influence the decisions of judges and juries to the same effect as when the defence of provocation was available, then abolition has not been effective in addressing the concerns regarding sentencing in these cases. A homicidal reaction to an unwanted homosexual advance should not be excusable in any way.

This unwillingness by judges to recognise the deaths of $\mathrm{Mr}$ Tunnicliffe and $\mathrm{Mr}$ Phillips as hate crimes deserving of more severe sentencing is disappointing. This paper suggests that one of the ways that this issue could have been addressed is through the establishment of a Sentencing Council, as recommended by the Law Commission in their 2007 Report. I will consider how a Sentencing Council could have made an important difference in terms of the use of s 9(1)(h), and to sentencing generally in homosexual advance cases.

\section{Sentencing Council}

The Sentencing Council Act was passed in 2007, and was to establish a Sentencing Council as an independent statutory body. The Sentencing Council's principal 
function would be to draft and declare sentencing guidelines for guidance of sentencing judges. ${ }^{69}$ Under the Act, the Sentencing Council was to be made up of four judicial members appointed by the relevant Heads of Bench, the chair of the Parole Board, and five non-judicial members appointed by the Governor-General on the recommendation of Parliament. ${ }^{70}$

A court would have to impose a sentence that was consistent with any guidelines relevant to the case, unless satisfied it would be contrary to the interests of justice to do so. The Law Commission's 2006 Report Sentencing Guidelines and Parole Reform found that there were marked inconsistencies in sentencing around New Zealand. ${ }^{71}$ One of the aims of the Sentencing Council Act was to achieve greater consistency in sentencing, which would mean more predictable outcomes. ${ }^{72}$

Some felt that the creation of a sentencing council was a threat to judicial independence. In his lecture "Chipping away at the Judicial Arm", John Priestly said that he thought that sentencing guidelines would have seriously restricted the discretion of sentencing judges to do justice in the wide range of cases over which they preside. He felt that the entire episode pointed to a tendency of Parliament to fetter the judicial arm. ${ }^{73}$ However the Report also asked whether it was any longer appropriate for sentencing policy to be left to the judiciary. ${ }^{74}$ The Law Commission stated that while the independence of judges in imposing impartial individual

\footnotetext{
${ }^{69}$ New Zealand Law Commission The Partial Defence of Provocation, above $\mathrm{n} 3$ at [188].

${ }^{70}$ Warren Young and Andrea King "Sentencing Practice and Guidance in New Zealand" at 257.

${ }^{71}$ New Zealand Law Commission Sentencing Guidelines and Parole Reform, (NZLC R 94, Wellington, 2006) at [20].

72 Young and King, above n 70 at 258.

${ }^{73}$ John Priestley “Chipping Away at the Judicial Arm?” (2009) 17 Waikato Law Review 1 at 21.

${ }^{74}$ At [43].
} 
sentences without influence from other branches of government is important, a democratically elected Government, who is in the position to take into account the concerns of the community, may more appropriately deal with the overarching policies under which sentences are imposed..$^{75}$ The Law Commission suggested the establishment of a sentencing council as a possible way to allow more involved public debate and input into sentencing policy. ${ }^{76}$ This means that there would have been more scope for community input into the aggravating and mitigating factors to be addressed in particular types of cases, including homosexual advance cases.

Graham Panckhurst stated that in order for the guidelines to be workable, they needed to be prescriptive enough to result in consistent sentencing, but that they also had to allow sufficient flexibility for judges to depart from the resulting sentence if they had compelling reasons to do so. ${ }^{77}$ If this had been achieved, judicial independence could have been maintained, and the Sentencing Council may have been able to succeed in ensuring greater consistency in sentencing.

Guidelines from the Sentencing Council could have allowed for much more detail than it is possible to achieve through guidance provided by legislation. A three step analysis was suggested in the proposed guidelines. This analysis required first that a judge first take into account the factual criminality of the offence, which would place the offence in the appropriate band of seriousness. The judge would then assess what point within this band best fits the culpability of the offender on a preliminary consideration, which would be the starting point for the sentence. Finally, the judge

\footnotetext{
${ }^{75}$ At [43].

${ }^{76}$ At [43].

${ }^{77}$ Graham Pankhurst “A Sentencing Council, Enlightened or Folly?” (2008) 14 Canta LR 191 at 200 at 204.
} 
would consider the individual circumstances of the offender, which may adjust the sentence from the starting point either up or down. ${ }^{78}$

Despite the Act having come into force, the National Government of the time, elected in 2008, indicated that it does not wish to proceed with sentencing guidelines. The Minister of Justice Simon Power stated that the National Government felt that a Sentencing Council was an extra layer of bureaucracy that was not needed. ${ }^{79}$ This is a disappointing outcome, as the guidance that a Sentencing Council would have provided could have been valuable for sentencing judges, particularly in dealing with homicide cases occurring after the abolition of provocation. This paper suggests that this applies particularly to homosexual advance cases, where there is a need for impartial sentencing that recognises the prejudiced motivation for these crimes, and reflects the concerns that surrounded the sentencing of these cases prior to the abolition of provocation.

The Sentencing Council would have been able to provide guidelines for how a judge should deal with homosexual advance situations, including direction on what level of provocation may lead to a finding of manifest injustice, and what aggravating and mitigating factors should have been considered. The Council would also have been helpful in that it could have ensured that the discriminatory effect of the defence of provocation against homosexual men did not continue through sentencing despite the repeal of s 169. This could have been achieved by requiring that any crime committed due to homophobia be recognised as a hate crime under s $9(1)(\mathrm{h})$. This mandatory recognition would then have ensured that an offender's sentence was aggravated

\footnotetext{
${ }^{78}$ Pankhurst, above $\mathrm{n} 77$ at 203.

${ }^{79}$ Pankhurst, above n 77 at 204.
} 
because of the hate crime status of the offence, which could have resulted in sentences more in line with community expectations in regard to the brutality of the violence inflicted.

This paper has shown that in homosexual advance cases that occurred both before and after the abolition of the defence of provocation, sentencing judges have consistently neglected to acknowledge the homophobic nature of the crimes as an aggravating factor of the offence. Guidance as to what may constitute a hate crime would have been helpful in ensuring that the homophobic motivation of offenders in homosexual advance cases was not overlooked.

\section{Conclusion}

This paper has argued that a man reacting in a homicidally violent manner when another man makes a non-violent sexual advance toward him is a homophobic response. Therefore, allowing the partial defence of provocation to categorise such a reaction as one of the ordinary person justifies of this type of homophobic violence. Because of this, the abolition of the partial defence of provocation was seemingly a positive event for the homosexual community of New Zealand, as it meant the defence of provocation could no longer be used as a way to normalise violence against homosexuals in the New Zealand courts. This paper discussed a sample of pre-abolition cases, which showed that this move against prejudice in homosexual advance cases was long overdue in the New Zealand legal system. 
However, as the case comparison in this paper shows, the abolition of the partial defence of provocation has so far made no substantial difference to sentencing in homosexual advance cases. This paper suggests that prejudice against homosexuals is still able to affect the way judges and juries decide in these cases. Alleged provocative actions of the victim may still be the underlying basis for manslaughter verdicts that are difficult to reconcile with the violence of the offender, such as in Ahsee, or for the imposition of the lowest possible minimum period of imprisonment for murder, as was given in Knight.

It is my view that this is because abolition of the partial defence was only one of the actions necessary to bring about the crucial change to the way these cases were being sentenced. Identification of these offences as hate crimes, and the recognition of that fact as an aggravating factor, is very important in denouncing violent reactions to homosexual advances or behaviour. However, sentencing judges in homosexual advance homicides have continued to overlook the relevance of $\mathrm{s} 9(1)(\mathrm{h})$ as an aggravating factor.

In order for the abolition of the partial defence of provocation to have the intended positive effect, judges need much clearer guidance on how to sentence in provocation cases post-abolition. The Court of Appeal guidance judgment of $R v$ Hamidzadeh set out basic principles for sentencing in post-abolition cases, but more specific guidance is needed for homosexual advance cases. As the Law Commission suggested, the establishment of a Sentencing Council could have been used to ensure that provocation was appropriately dealt with, and could also have allowed for community input into sentencing policy. 
This paper argued that sentencing guidelines could have given more specific direction to sentencing judges in cases where provocation had allegedly been the cause of the offence. These guidelines would have been particularly helpful where the provocation being alleged was a homosexual advance. This is because guidelines could have been drafted to ensure that $\mathrm{s} 9(1)(\mathrm{h})$ was considered, and community concerns were addressed to ensure that more appropriate sentences were imposed upon the homophobic killers of gay men. If homosexual advance offenders continue to be given sentences that do not seem to fit their violent crimes, the legal legitimisation of violence against homosexual men endures. It is my submission that this problem needs to be addressed directly, and that this could have been done through sentencing guidelines that required recognition of these offences as hate crimes, and sentences appropriate for the level of violence inflicted. The decision not to establish a Sentencing Council has meant that judges in homosexual advance cases have been left without suitable guidance, and therefore the concerns surrounding sentencing in these cases remain. 


\section{Bibliography}

A Cases

Hamidzadeh v R [2012] NZCA 550.

$R v$ Ahsee, CRI-2010-055-2018, 15 December 2011.

$R v$ Ali CRI2003-292-1224, 19 August 2004.

$R v$ Ali \& Nadan CRI-2003-292-1224, 22 July 2004.

$R v$ Ambach CRI-2007-004-27374, 18 September 2009.

$R v$ Knight [2012] NZHC 2866.

$R$ v Rapira [2003] 3 NZLR 794.

$R v$ Taueki [2005] 3 NZLR 372.

$R v$ Weatherston [2011] NZCA 276.

\section{B Legislation}

Sentencing Act 2002.

\section{Articles}

A J Ashworth “The Doctrine of Provocation” (1976) 35 Cambridge LJ 292.

Warren J Brookbanks "'I lost it' - rage and other excuses: rethinking loss of selfcontrol in provocation" (2006) 31 Alt LJ 186.

Gary Comstock "Dismantling the Homosexual Panic Defense" (1992) Law and Sexuality 81.

Joshua Dressler "When 'Heterosexual' Men Kill 'Homosexual' Men: Reflections on Provocation Law, Sexual Advances, and the 'Reasonable Man' Standard" (1995) 85 J Crim L \& Crim 726.

Edward Gay "Partial defence of provocation set to be dumped" The New Zealand Herald <nzherald.co.nz>. 
Ben Golder, 'The Homosexual Advance Defence and the Law/Body Nexus: Towards a Poetics of Law Reform' (2004) 11:1 E Law: Murdoch University Electronic Journal of Law.

Adrian Howe "More Folk Provoke Their Own Demise (Homophobic Violence and Sexed Excuses - Rejoining the Provocation Law Debate, Courtesy of the Homosexual Advance Defence)" (1997) 19 Sydney LR 336.

John Ip "Debating New Zealand's Hate Crime Legislation: Theory and Practice" (2005) 21 NZULR 575.

Alison Laurie "'Homosexual Panic' defence must go" The New Zealand Herald <www.nzherald.co.nz>.

Cynthia Lee "The Gay Panic Defense” (2008) 42 UC Davis LR 471.

Scott D McCoy "Homosexual-Advance Defence and Hate Crime Statutes: Their Interaction and Conflict” (2001) 22 Cardozo LR 629.

Elisabeth McDonald "No Straight Answer: Homophobia as Both an Aggravating and Mitigating Factor in New Zealand Homicide Cases” (2006) 37 VUWLR 223.

Robert Mison "Homophobia in Manslaughter: The Homosexual Advance as Insufficient Provocation" (1992) 80 Cal LR 133.

Graham Pankhurst “A Sentencing Council, Enlightened or Folly?” (2008) 14 Canta LR 191.

Christina Pei-Lin Chen "Provocation's Privileged Desire: The Provocation Doctrine, 'Homosexual Panic', and the Non-Violent Unwanted Sexual Advance" (2000) 10 Cornell JL \& Pub Pol 195.

John Priestley "Chipping Away at the Judicial Arm?” (2009) 17 Waikato Law Review 1.

Antony Whitehead "Man to Man Violence: How Masculinity May Work as a Dynamic Risk Factor" (2005) 44 How J Crim Just 411.

Warren Young and Andrea King "Sentencing Practice and Guidance in New Zealand".

\section{Books}

Elisabeth McDonald "Provoking Law Reform: Feminism, Queer Theory and the Legislative Agenda" in Claire Chambers and Dean Knight (eds) We the People(s) (Victoria University Press, Wellington, 2011) 237.

\section{E Law Commission Reports}


New Zealand Law Commission Sentencing Guidelines and Parole Reform, (NZLC R 94, Wellington, 2006).

New Zealand Law Commission Some Criminal Defences with Particular Reference to Battered Defendants (NZLC R 73, Wellington, 2001).

New Zealand Law Commission The Partial Defence of Provocation, (NZLC R 98, Wellington, 2007).

\section{F Websites}

<http://nzdotstat.stats.govt.nz> Statistics NZ Website. 


\section{Word count}

The text of this paper (excluding table of contents, footnotes, and bibliography) comprises approximately 7,870 words. 